\title{
Dual Degree Program (PharmD/MPH or PharmD/ MBA) and Student Pharmacists Opinion Survey
}

\author{
Mercy Nyamor ${ }^{1}$, Kelechi Kalu ${ }^{1}$, Michel Gakpara ${ }^{1}$ and Bisrat Hailemeskel ${ }^{* 2}$ \\ ${ }^{1}$ College of Pharmacy, Howard University, USA \\ ${ }^{2}$ Department of Clinical \& Administrative Pharmacy Sciences, College of Pharmacy, Howard University, NW Washington, USA
}

*Corresponding author: Bisrat Hailemeskel, Professor \& Vice Chair, Department of Clinical \& Administrative Pharmacy Sciences, College of Pharmacy, Howard University, NW, Washington, DC 20059, USA

\section{ARTICLE INFO \\ Received: 彗April 21, 2021}

Published: 彗 May 24, 2021

Citation: Mercy Nyamor, Kelechi Kalu, Michel Gakpara, Bisrat Hailemeskel. Dual Degree Program (PharmD/MPH or PharmD/MBA) and Student Pharmacists Opinion Survey. Biomed J Sci \& Tech Res 36(1)-2021. BJSTR. MS.ID.005789.

\section{ABSTRACT}

Background: Dual degree programs are typically faster than just receiving each degree individually and it is also a way to save money while earning education. It is believed that participating in a dual degree program puts one on a faster track. It helps to have a wider range of job positions. Most students do not learn about dual degree programs early enough. This program can help you save money because you are getting two types of degrees.

Objective: The objective of this study is to survey students and see their knowledge and opinions on dual degree programs after graduation. Also, to observe and see if participants believed enrolling in this program would be mentally and financially stressful and also if it increases their base income upon graduation.

Methods: Electronic surveys were conducted to pharmacy students to see if they were more likely to be interested in the dual degree program or not. The questions on the survey were very specific to see the students' personal opinions on jobs after graduation and if participating in the program would open more doors for them for a wider range of job opportunities.

Results: A total of 44 students participated with 100 percent response rate. Majority of the students were females and at least a four-year degree program (30;n=64.2\%). Over three-quarter of the participants $(n=22 ; 77.2 \%)$ either strongly or somewhat agree that involvement in a dual degree program increases their chance of finding a job after graduation. Over eighty percent of them $(n=36 ; 81 \%)$ say they strongly believe having a dual degree gives them a wider range of job opportunities and a higher salary $(n=35$; $79.6 \%)$. However, only about half the participants $(n=22 ; 56.8 \%)$ believe that someone with a dual degree is more qualified for a job than someone with just a single (PharmD) degree. When asked about their motivation in pursuing a dual degree, about two-third $(n=29 ; 65.9 \%)$ say they are motivated to consider the dual degree program while they are still in the pharmacy program. Despite their belief regarding the benefits of having a dual degree only about half of them $(n=23 ; 52.3 \%)$ say it may not be for them because of their other social and financial commitments. About sixty percent $(n=26 ; 59.1 \%)$ say they believe in having a dual degree, but they prefer to do it after graduation once they have a job but not while they are still in pharmacy school.

Conclusion: Our results revealed that overall, the students that participated in the survey agreed that having a dual degree is beneficial, gives more opportunity in finding jobs faster, and leads to earning a higher income. Participants are highly motivated in the program, about half of them may not consider joining while in the pharmacy program because of personal or financial reasons but they will consider it after graduated. 


\section{Introduction}

Dual degree programs are programs that have many advantages that come with them. Dual degree programs are typically faster than just receiving each degree individually and it is also a way to save money while earning education. Having a dual degree is also a way that can open many doors for individuals to have several options in the professional field. According to articles done by several pharmacy schools, the majority of students involved in the research agreed that employment opportunities following graduation were a big influence in regards to if they should pursue an MBA or not. A survey was done by Holtzman to determine the Doctor of Pharmacy (PharmD) students' perceptions of a PharmD and Master of Public Health Dual Degree (MD/MPh). There was a seven instrument that was developed and used among a total of 611 students. Among the PharmD students involved in the survey, only $73 \%$ responded, most of the $73 \%$ responded with a "likely" or "very likely" to consider enrolling into a dual degree program. In another study by Gortney, an 18-item survey instrument was developed to assess the prevalence and characteristics of curriculum in dual doctor of degree programs and Master of Public Health degree. The survey was distributed online to faculty members in colleges and pharmacy schools. There were 110 colleges and out of those, only 23 offered the dual degree program. The 23 programs included current PharmD program structure, early curricular recruitment, small enrollment, and interdisciplinary coursework occurring online and in the classroom.

Another survey study was done to understand Pharmacy Students reason for pursuing a dual PharmD and Master of Business Administration (PharmD/MBA). A cross-sectional study was conducted and there was also an electronic questionnaire developed. Majority of the students responded to the questionnaire, a total of $23 / 24$. The students involved in this study came to the conclusion that opportunities and career advancement after graduation had the most impact in deciding whether or not to pursue a n MBA. One hundred percent of these students believed that the job marketplace for PharmD graduates was very difficult, $96 \%$ believed that by having a dual degree there would be a chance of higher pay, and $2 \%$ said they would recommend the dual program to first year students. A similar study was conducted to update current literature on the characteristics of dual (PharmD/MBA) programs in the United States. In this study, only sixty-six pharmacy schools were included. It provided updated information about the characteristics of dual PharmD/MBA programs across the United States such as program history, student and school demographics, enrollment requirements, and program structure. In the last article, the growth and evolution of the pharmacy profession has created a wide array of opportunities for graduating pharmacists. The wide array of opportunities includes Management and leadership positions in federal and state healthcare agencies, pharmaceutical companies, hospitals, retail pharmacies, academia and managed care. Each one of these studies showed the importance of a dual degree program. From providing different opportunities to the advantages of having a dual degree. The research that has been done by several universities each have different points of views on these programs. The objective of this study is to survey students and see their knowledge and opinions on dual degree programs after graduation and their motivation in enrolling in these programs.

\section{Methods}

Electronic surveys were conducted to first professional year pharmacy students to see if they were more likely to be interested in the dual degree program or not. There were several demographic questions that were asked during the survey. These questions consisted of what state you lived in before attending pharmacy school, if you worked or had a job, income from your job if you have worked, what kind of job you did prior to pharmacy school and how long you held that job and also the highest degree obtained before pharmacy school in addition to other questions. Statistical analysis was conducted using Statistical Package for the Social Sciences (SPSS) at an alpha level of 0.05 .

\section{Results}

There were a total of 44 participants in this study with 100 percent response rate. The demographics of this population was represented by a majority female (males $n=34 ; 77.3 \%$ vs. females $\mathrm{n}=10 ; 22.7 \%$ ). There was a specific age range that was conducted in this study, the study consisted of people mostly at the age range of 18-24 ( $n=25 ; 58.1 \%)$, with ages 25-34 ( $n=18 ; 41.9 \%)$. Most of the students that accepted admission to Howard College of Pharmacy were mostly moved from other states ( $n=19 ; 41.3 \%)$. Students from Washington, DC were 9.1\% ( $\mathrm{n}=4)$, students from Maryland were $27.3 \%(n=12)$ and students from Virginia were $20.5 \%(n=9)$. Majority of the students that participated in the survey answered that they have had jobs prior to being accepted into pharmacy school. The annual income range for the students who worked prior to pharmacy school less than $\$ 10,000$ was $38.6 \%$ ( $n=17)$, and the ones that had annual income of greater than $\$ 49,000$ was $11.4 \%$. There was a tied percentage between people who made $\$ 20,000$ $\$ 29,000$ and the ones that made $\$ 40,000-\$ 49,000$, that percentage was $6.8 \%$. Majority of the students that participated in the survey checked that they had completed a four-year degree program with a percentage of $59.1 \%(n=26)$ while $27.3 \%(n=12)$ of the students completed some college. A small percentage of the participants had professional education at $9.1 \%$. The students that had the least amount of education were the ones that had two years of college experience with $4.5 \%$. With most of the students stating that they had previous work experience before pharmacy school were 91.3\% ( $\mathrm{n}=42)$. The non-related pharmacy jobs had 20.5\% ( $\mathrm{n}=9)$ and the non-related pharmacy or healthcare related occupations had $15.9 \%$. Majority of the people that worked prior to attending 
Howard University were the ones that worked between 1-3years $31.8 \%(n=14)$. The ones that worked less than a year were $16.28 \%$ and there was a tie between 4-5 years and the ones that worked more than 5 years with a percentage of $25.58 \%$ [1-5].

In addition to all the demographic-related survey questions, there were other additional questions regarding the dual degree program and if the participants agreed or disagreed with the questions asked. Over three-quarter of the participants $(n=22$; $77.2 \%$ ) either strongly or somewhat agree that involvement in a dual degree program increases their chance of finding a job after graduation. Over eighty percent of them $(n=36 ; 81 \%)$ say they strongly believe having a dual degree gives them a wider range of job opportunities. However, only about half the participants $(n=22$;

Table 1.
$56.8 \%$ ) believe that someone with a dual degree is more qualified for a job than someone with just a single (PharmD) degree. When asked about their motivation in pursuing a dual degree, about two-third (n=29; 65.9\%) say they are motivated to consider the dual degree program while they are still in the pharmacy program. Overwhelming number of participants $(n=35 ; 79.6 \%)$ agreed that having a dual degree contributes to a higher base income. Despite their belief regarding the benefits of having a dual degree only about half of them $(n=23 ; 52.3 \%)$ say it may not be for them because of their other social and financial commitments. About sixty percent $(n=26 ; 59.1 \%$ ) say they believe in having a dual degree, but they prefer to do it after graduation once they have a job but not while they are still in pharmacy school (Tables 1 \& 2).

\begin{tabular}{|c|c|}
\hline Gender & $\mathrm{N}(\%)$ \\
\hline Female & $34(77.3)$ \\
\hline Male & $10(22.7)$ \\
\hline Age & $\%$ \\
\hline $18-24$ & $25(58.1)$ \\
\hline $25-34$ & $18(41.9)$ \\
\hline State Lived Before Howard & $\%$ \\
\hline Washington, DC & $4(9.1)$ \\
\hline Maryland & $12(27.3)$ \\
\hline Virginia & $9(20.5)$ \\
\hline Other States & $19(43.2)$ \\
\hline Worked or had a Job Before Pharmacy & $\%$ \\
\hline No & $2(4.5)$ \\
\hline Yes & $42(95.5)$ \\
\hline Annual Income from your Job if you have worked & $\%$ \\
\hline$<\$ 10 \mathrm{~K}$ & $17(38.6)$ \\
\hline$\$ 10 \mathrm{~K}-\$ 19 \mathrm{~K}$ & $7(15.90$ \\
\hline$\$ 20 \mathrm{~K}-\$ 29 \mathrm{~K}$ & $3(6.08$ \\
\hline$\$ 30 \mathrm{~K}-\$ 39 \mathrm{~K}$ & $8(18.2)$ \\
\hline$\$ 40 \mathrm{~K}-\$ 49 \mathrm{~K}$ & $3(6.8)$ \\
\hline$>\$ 49 \mathrm{~K}$ & $5(11.4)$ \\
\hline Kind of Work Experience & $\%$ \\
\hline Pharmacy Related & $27(61.4)$ \\
\hline Non-Pharmacy Related & $9(20.5)$ \\
\hline Non-Rx or Healthcare Related & $7(15.9)$ \\
\hline Years of Work Experience & $\%$ \\
\hline$<1 \mathrm{yr}$ & $7(15.9)$ \\
\hline $1-3 y r$ & $14(31.8)$ \\
\hline $4-5 y r$ & $11(25.0)$ \\
\hline$>5 \mathrm{yr}$ & $11(25.0)$ \\
\hline Highest Education Prior to Pharmacy & $\%$ \\
\hline Some College & $12(27.3)$ \\
\hline 2 Years College & $2(4.5)$ \\
\hline 4 Years College & $26(59.1)$ \\
\hline Professional & $4(9.1)$ \\
\hline
\end{tabular}


Table 2.

\begin{tabular}{|c|c|c|c|c|}
\hline & Strongly Agree & Somewhat Agree & Somewhat Disagree & Strongly Disagree \\
\hline $\begin{array}{l}\text { Having a dual degree program increases my chances } \\
\text { of finding a job right after graduation }\end{array}$ & $17(38.6 \%)$ & $17(38.6 \%)$ & $8(18.2 \%)$ & $2(4.5 \%)$ \\
\hline $\begin{array}{l}\text { I strongly believe having a pharmacy dual degree } \\
\text { program gives a wider range of job positions }\end{array}$ & $21(47.7 \%)$ & $15(34.1 \%)$ & $5(11.4 \%)$ & $3(6.8 \%)$ \\
\hline $\begin{array}{l}\text { I believe that someone with a dual degree is more } \\
\text { qualified for a job than someone with just a PharmD } \\
\text { Degree }\end{array}$ & $7(15.9 \%)$ & $18(40.9 \%)$ & $10(22.7 \%)$ & $9(20.5 \%)$ \\
\hline $\begin{array}{l}\text { I am motivated to pursue a dual degree program } \\
\text { while I am still in pharmacy }\end{array}$ & $7(15.9 \%)$ & $22(50.0 \%)$ & $8(18.2 \%)$ & $7(15.9 \%)$ \\
\hline $\begin{array}{l}\text { I strongly agree that having a dual degree increases } \\
\text { my base income }\end{array}$ & $19(43.2 \%)$ & $16(36.4 \%)$ & $7(15.9 \%)$ & $2(4.5 \%)$ \\
\hline $\begin{array}{l}\text { Although I believe in the benefit of having a dual } \\
\text { degree, it is not for me because of my other social and } \\
\text { financial commitments }\end{array}$ & $7(15.9 \%)$ & $14(31.8 \%)$ & $11(25.0 \%)$ & $12(27.3 \%)$ \\
\hline $\begin{array}{l}\text { I believe adding another year and additional } \\
\text { workload to get a dual degree will give me more } \\
\text { stress both mentally and financially. }\end{array}$ & $11(25.0 \%)$ & $23(52.3 \%)$ & $6(13.6 \%)$ & $4(9.1 \%)$ \\
\hline $\begin{array}{c}\text { I believe in having another degree such as MBA } \\
\text { degree, but I wanted to do it after graduation once } \\
\text { I have a job but not now while I am in pharmacy } \\
\text { school. }\end{array}$ & $6(13.6 \%)$ & $20(45.5 \%)$ & $13(29.5 \%)$ & $5(11.4 \%)$ \\
\hline
\end{tabular}

\section{Discussion}

The survey answered exactly the goal of this study, which was to see the opinion of students on if a dual degree will increase their chances of receiving a job after graduation. The main focus on this study was to have genuine and honest opinions without students being persuaded to agree that this program would be beneficial. The results from this study indicated that the majority of the participants that participated in the survey agreed that having a dual degree will increase their chances of receiving a job after graduation. Receiving a dual degree meant staying in school longer, but the benefits were better. It meant that their base increase would increase, the majority of the students agreed that this was right. The result in this study shows us that dual degree programs can be useful and effective for pharmacy students to continue to grow professionally. It helps them grow professionally by being able to receive two degrees at once, which broadens the job market making it not as difficult to receive a job. Some of the students did agree that it would be costly to participate in a dual degree program while also being in pharmacy school. They still agreed and stated that having a dual degree would be beneficial. One of the limitations of the study was that there were only 8 survey questions asked that were regarding the dual degree programs. The questions that were asked helped us understand the opinion of the students on the dual degree program. Another limitation of the study was the small number of participants. However, the majority of the students that completed the survey answered all the questions.

\section{Conclusion}

The results during this research concluded that students do think dual degree programs are helpful in receiving jobs after graduation. They also agreed that it would help with their chances of jobs. They believed that it not only helped give students get jobs, but they were more likely to have a wider range of job positions.

\section{References}

1. Gortney JS, Seed S, Borja Hart N, Veronica Young, Lisa J Woodard, et al. (2013) The prevalence and characteristics of dual PharmD/MPH programs offered at US colleges and schools of pharmacy. American Journal of Pharmaceutical Education 77(6): 116.

2. Holtzman CW, Sifontis NM (2014) Pharmacy students' perspectives on a PharmD/MPH dual degree program at a large metropolitan school of pharmacy. Pharmacy Practice 12(1): 359.

3. Jacobs DM, Daly CJ, Tierney S EL, Obrien E, Fiebelkorn KD (2017) Attitudes and Perceptions of Dual PharmD/MBA Degree Program Students. American Journal of Pharmaceutical Education 81(4): 71.

4. Salmon K, Fan J (2019) An update on characteristics of dual PharmD/ MBA programs in the United States: 2016-2017. Currents in Pharmacy Teaching and Learning 11(5): 469-475.

5. Senft SL, Thompson C, Blumenschein K (2008) Dual Degree Programs at the University of Kentucky College of Pharmacy. American Journal of Pharmaceutical Education 72(1): 12. 
ISSN: 2574-1241

DOI: 10.26717/BJSTR.2021.36.005789

Bisrat Hailemeskel. Biomed J Sci \& Tech Res

(C) (9) This work is licensed under Creative

Submission Link: https://biomedres.us/submit-manuscript.php

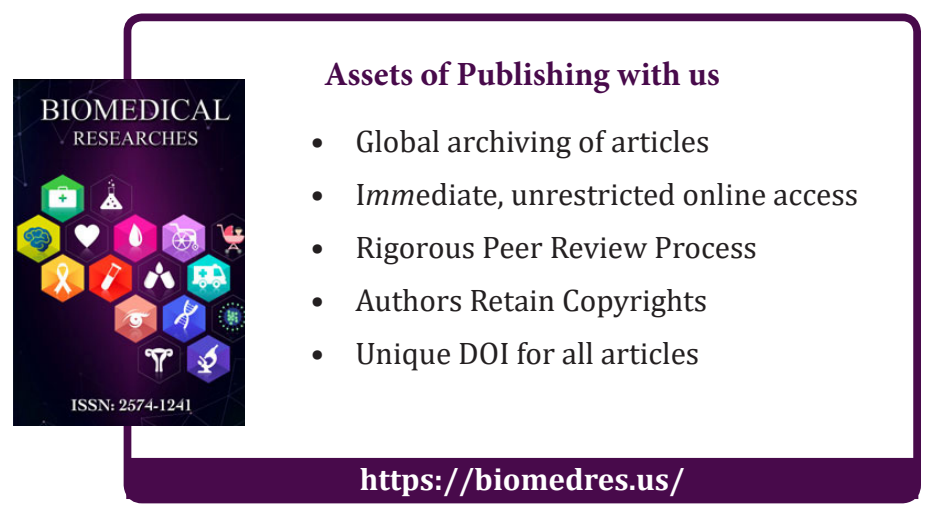

